\title{
The Witches' Broom Disease of Pigeon pea (Cajanus cajan (L.) Millsp.) in Puerto Rico'
}

\author{
Margarita Licha-Baquero ${ }^{2}$
}

\begin{abstract}
Studies were undertaken to determine the cause of the so called witches' broom disease of pigeon pea in Puerto Rico. Typical witches' broom occurs when leafhoppers of the Empoasca fabae complex colonize (in numbers) on field plants. The disease can be reproduced under controlled conditions and can be eliminated by suppression of the insects. Mycoplasma-like organisms were found to be associated with a bushy canopy disease of the pigeon pea plant. This condition should not be confused with the typical witches' broom. No rhabdovirus particles were found in association with the bushy canopy or typical witches' broom diseases. Electron microscopy of tissues from pigeon pea plants with a pale mosaic revealed the presence of rhabdovirus particles. No mycoplasma-like organisms have been found so far in tissues affected by the pale mosaic. No mixed infections were detected in the present studies.
\end{abstract}

\section{INTRODUCTION}

Pigeon pea (Cajanus cajan (L.) Millsp.) is a tropical edible grain legume supposedly of Indian or African origin (23, 32). It is usually a short term perennial shrub with hairy narrow lanceolate trifoliolate leaves. Its flowers, usually yellow or brown, are borne in terminal racemes and the pods generally contain four to six seeds. It has a wide range of rainfall tolerance and requires no fertilizers as far as yield is concerned. Its protein content ranges from $16-30 \%(1,23,32)$.

Pigeon peas have been known as a crop with only minor disease problems. In a survey of the world literature on pigeon pea diseases, Barnes (2) recognized 20 of fungal origin, two caused by bacteria, two of unknown etiology and six caused by viruses (cowpea mosaic, pale mosaic, mosaic, Rhynchosia mosaic, sterility disease, and yellow mosaic). A new virus affecting this legume was recently reported by Singh et al. (27) in India. Symptomatology and physical properties differ from those associated with other viruses infecting pigeon pea.

Phoma sp., Colletotrichum cajani, Phytophthora parasitica and Pellicularia filamentosa are among the fungal pathogens affecting the crop in Puerto Rico; Rhynchosia and cowpea mosaics have also been reported to affect pigeon peas (3). Spence (33) stressed the need for a survey of diseases of this crop in the Caribbean basin countries to assess losses due

${ }^{1}$ Manuscript submitted to Editorial Board September 21, 1979.

${ }^{2}$ Research Assistant, Department of Crop Protection, Agricultural Experiment Station, University of Puerto Rico, Mayagüez Campus, Rio Piedras, P.R. Part of a thesis submitted by the author in partial fulfillment of the requirements for M.S. at the College of Agricultural Sciences of the University of Puerto Rico, Mayagüez Campus. The author wishes to express her appreciation to her major professor, Dr. Julio Bird, for his guidance during this study. 
to the maladies and determine which, of the lesser ones, are most likely to become important.

A witches' broom disease of pigeon pea (Cajanus cajan (L.) Millsp.) was discovered several years ago and at present is well distributed throughout the island of Puerto Rico (35).

Heretofore, in spite of its increasing importance, the disease had not received due attention in Puerto Rico. Plants affected by witches' broom are characterized, according to Hirumi et al. (13) and Maramorosch et al. $(18,20)$, by smaller leaves and branches which become pale green (and eventually chlorotic) and cluster in a witches' broom fashion. These symptoms are similar to those caused by mycoplasma-like organisms
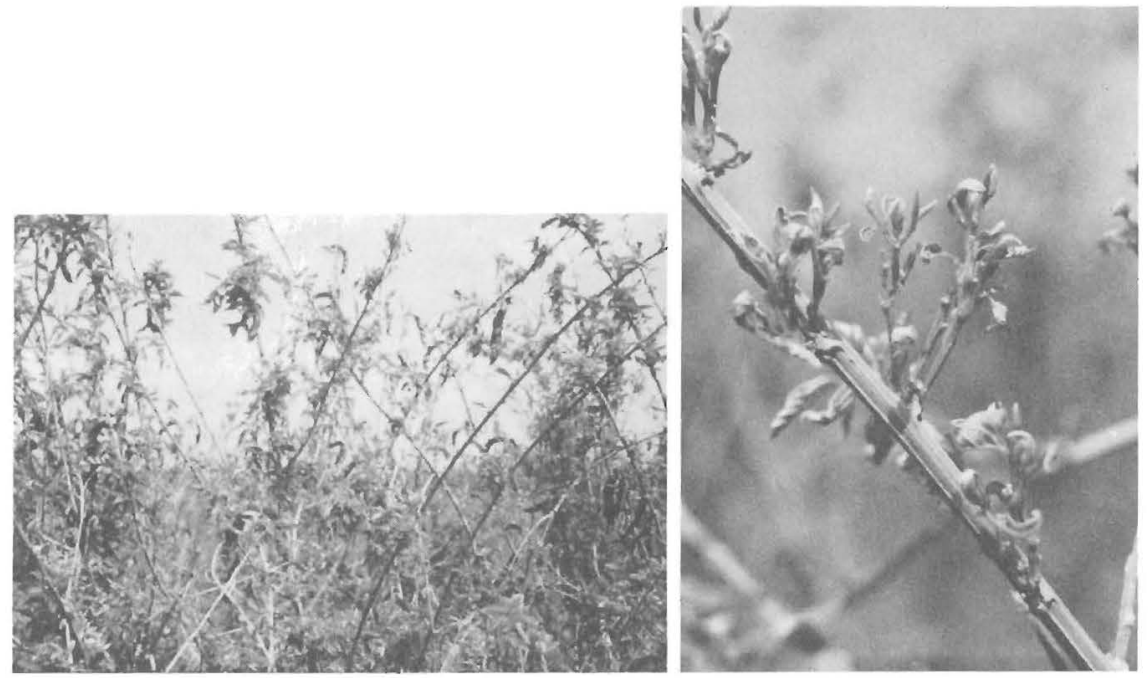

FiG. 1.-Pigeon pea plants severely affected by the witches' broom disease.

(MLO) in other crops $(3,4,7,17,20,35)$. Some investigators (18) believe that witches' broom is caused by a mycoplasma and a virus. However, witches' broomed plants, diagnosed by supporters of the theory that the malady is caused by infectious entities, have recovered from symptoms when kept under presumably-insect-proof conditions in screened insectaries.

Electron microscopy (EM) studies of a similar disease in the Dominican Republic indicated that the disease was associated with a mycoplasma or a virus or a combination of both agents (18).

In September 1976 a serious outbreak of the malady was observed by the writer at the Isabela Substation (figs. 1, 2). The disease was found affecting pigeon pea plants in several experimental fields. The plants 
were, in all cases, heavily infested with leafhoppers of the genus Empoasca.

Witches' broom is at times a crippling disease and whole plantations may become affected. Plants affected early in their development fail to produce entirely, or the yields may be substantially reduced. At times, affected plants may produce a few small unmarketable pods with minute peas.

In view of the different opinions regarding the etiology of the pigeon pea witches' broom disease and considering its importance from the economic as well as from the scientific standpoints, studies were undertaken in an attempt to determine its cause or causes. Concomitantly,
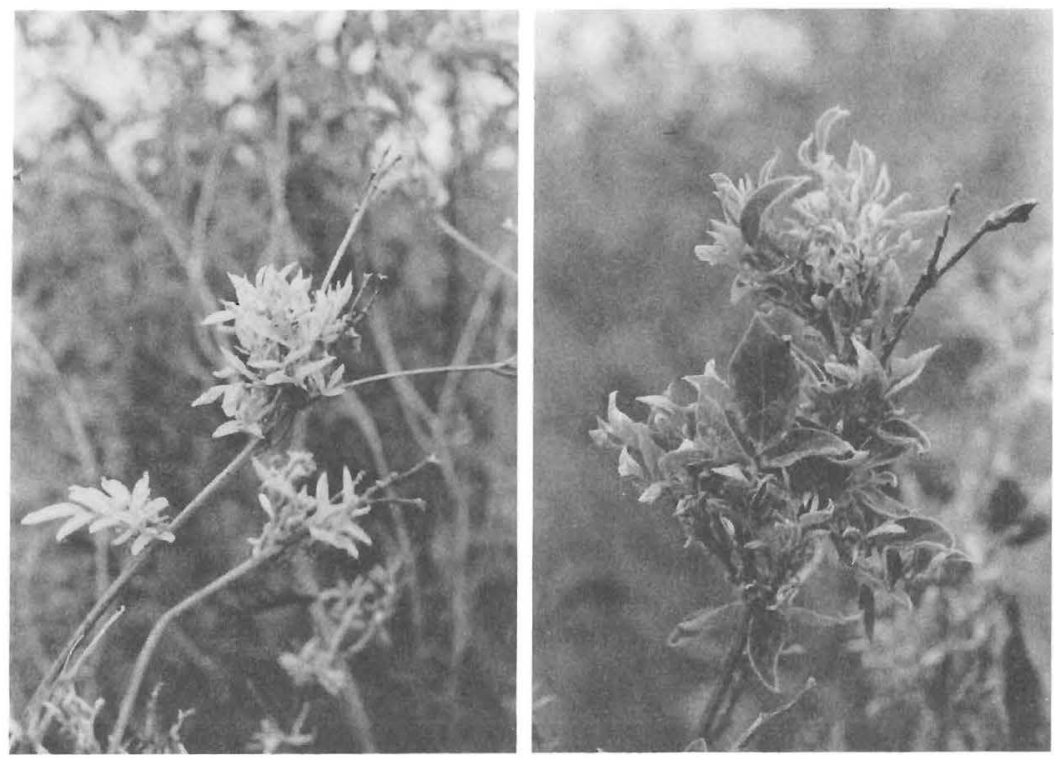

FIG. 2.-Supernumerary axillary shoots in plants affected by witches' broom disease.

efforts were made to develop practical means for controlling it under field conditions.

\section{REVIEW OF LITERATURE}

The witches' broom disease of pigeon pea was first reported in the western part of Puerto Rico by Vakili et al. (35). Mycoplasma-like organisms (MLO) were found to be associated with the disease by these investigators who studied thin sections of affected tissues under the electron microscope (EM). It was suggested that a leafhopper of the genus Empoasca was responsible for spreading this malady.

Pigeon pea plants with a proliferation disease similar to the local 
witches' broom have been previously observed in the Dominican Republic by Hirumi et al. (24), who studied thin sections of diseased tissues under the EM. Mycoplasma-like organisms were detected in the phloem elements.

In 1974 ultrathin sections made from witches' broom-affected plant parts collected at Río Piedras and Mayagüez were studied under the EM (32). The samples from Mayagüez showed large accumulations of MLO in the sieve tube elements. Rhabdovirus particles were also detected in this material. Similar sections from leaf-curled (not witches'-broomed) plants collected at Río Piedras were found to be free of MLO. At time of collection, leafhoppers of the genus Empoasca were present on the plants of both localities. The authors suggested that the distortion at Río Piedras could be caused by a leafhopper toxin rather than by a plant pathogenic agent, whereas the witches' broom disease at Mayagüez was associated with MLO and a virus, and was thought to be the result of the combined action of a toxin from Empoasca, MLO, and a virus.

A witches' broom disease of pigeon pea associated with MLO has also been reported from Hyderabad, India (27). The organism was found in the phloem elements and phloem parenchyma. It was pleomorphic and its size ranged from $80-100 \mathrm{~nm}$ in diameter. Plants affected by the malady were chlorotic and had short internodes and bushy appearance. Flowers and pods were produced but yield was depressed by the disease.

Leafhoppers of the genus Empoasca (Homoptera:Cicadellidae) and other members of the Homoptera:Cicadellidae group are provided with piercing and sucking mouthparts. They are very prolific and may produce several overlapping generations per year $(5,22)$. These insects are known to induce plant malformations, spotting, yellowing, leaf-curling and stunting as a result of their feeding.

Insects of this group have long been known to cause phytotoxemias. They also transmit mycoplasma and viruses $(10,11,13,15,16,19,26,29$, 31).

Rhabdoviruses are generally transmitted by aphids or by leafhoppers and have been divided in two groups on the basis of that vector specificity. Rhabdovirus particles have been recovered from the hemolymph, intestinal organs $(9,28,31)$, and salivary glands of their insect vectors $(13,28$, 30,31 ).

These viruses may incite severe chlorosis and necrosis and are not, in general, easily transmitted by sap inoculation. Most seem to have a limited host range (8). Transmission of most rhabdoviruses seems to be propagative in their vectors with a long incubation period, after which the insect remains viruliferous for life (8).

In some instances rhabdovirus particles are found in association with MLO. Fedotina (7) claims that in oat plants infected by pseudorossette 
disease, the virus is responsible for a leaf mosaic and intracellular inclusions and MLO are responsible for ear proliferation. Later Fedotina (1977) concluded that the disease represents a natural association of a rhabdovirus and a MLO. Vago (34) attributes the simultaneous presence of different types of pathogens to a factor favoring their absorption by a single vector and their retransmission as a pathological factor. Ploaie (25) in a study about the presumptive agent of clover dwarf disease presents electron micrographs which suggest the existence of a rod-shaped virus which infects the mycoplasma or is transmitted by mycoplasma.

MLO are generally found in association with plants affected by yellows diseases (17). These agents are usually associated with the phloem components $(15,17,21,24)$. Typical symptoms of yellows include excessive and premature development of buds, shortening of internodes, reduction in leaf size, growth of adventitious shoots, chlorosis, vein clearing and sterility among other symptoms.

\section{MATERIALS AND METHODS \\ GREENHOUSE EXPERIMENTS}

\section{Transmission studies}

In the greenhouse, mechanical inoculation was attempted with juices extracted from pigeon pea plants affected with witches' broom disease. The leaves were pounded in the presence of phosphate buffer ( $\mathrm{pH} 7.0$ ) and pressed through cheesecloth. The extract (inoculum) was maintained at low temperature (ice bath) throughout the inoculation procedure. A small quantity of Carborundum (600 mesh) was dusted on the leaves prior to inoculation. The inoculum was rubbed gently on the upper surface of the top most leaves (3) of test plants by means of a cotton swab. The leaves were rinsed with water after inoculation. Two pigeon pea varieties (02115 and Kaki), beans, cowpea, cucumber, tobacco, $\mathrm{Ni}$ cotiana glutinosa, Chenopodium amaranticolor and Capsicum annuum were inoculated. Their respective control plants (1:1 rate) were blank inoculated following the same procedure and were also rinsed with water.

Several grafting techniques were used (budding, cleft grafts, approximation and bottle grafts) in an effort to transmit the agent of the disease. Reciprocal grafts (healthy on diseased and diseased on healthy) were also practiced.

Transmission was also attempted with the surgical cannula grafting method (6). Cores of tissue removed from 15 diseased plants (with the cannula) were inserted into stems of healthy plants from which similar cores had been removed.

\section{Studies on remission of symptoms}

Two groups of healthy pigeon pea plants (50 of each) of the aforementioned varieties were colonized in the greenhouse with leafhoppers of the 
Empoasca fabae complex collected from plants with typical witches' broom symptoms. After 10 days, the insects of one group of plants were destroyed with an organic phosphate (Malathion), while the other group (disease control) remained colonized.

\section{Effect of the number of insects on incidence and severity of symptoms}

Plants of two pigeon pea varieties (02115 and Kaki) in the three-leaf stage and another group in the six-leaf stage were maintained in the greenhouse during 2 months and colonized with different numbers, i.e., 1 , $5,10,25$, and 50 insects per unit, every unit consisting of four caged plants in a pot. These insects were counted daily and replaced as they died. Each unit was isolated within a cylindrical Plexiglass (acrylic) cage. The leafhoppers were collected in the field from plants presenting typical witches' broom symptoms. Plastic suction type collecting tubes were used to collect the insects.

\section{ELECTRON MICROSCOPY}

Leaf tissues from pigeon pea plants exhibiting typical witches' broom symptoms, from naturally infected and greenhouse inoculated material, were processed for electron microscopy.

The samples were processed by two different methods. In the first method, fixation was effected in $1.5 \%$ glutaraldehyde in a .1 $\mathrm{M}$ sodium cacodylate buffer solution at pH 7.3 (overnight). Four washings in buffer plus .18 M sucrose (at 30-min intervals between changes) followed. The samples were washed in cold double-distilled water for a few minutes. Post-fixation was completed in $2 \% \mathrm{OsO}$ (in .1 M sodium cacodylate buffer, $.18 \mathrm{M}$ sucrose) for $2 \mathrm{~h}$. Dehydration followed in a graded series of ethyl alcohol. The alcohol was evaporated with propylene oxide followed by Epon mixture plus propylene oxide in a 1:1 proportion. The material thus treated was collected in no. 00 plastic capsules. Polymerization with Epon took place during $2-5$ days in an oven at $60^{\circ} \mathrm{C}$.

The second method used was similar to the one recommended for MLO (17) with some modifications (12). Fixation took place in $6 \%$ glutaraldehyde in .1 $\mathrm{M}$ phosphate buffer at $\mathrm{pH} 7.2$ for $2 \mathrm{~h}$ at room temperature. The pieces were rinsed in phosphate buffer, four washings of a few minutes each. This was followed by post-fixation for $2 \mathrm{~h}$ at room temperature in $2 \% \mathrm{OsO}$ in .1 M phosphate buffer $\mathrm{pH}$ 7.2. The fixed material was dehydrated in a graded series of ethyl alcohol, followed by infiltration with propylene oxide, propylene oxide plus Epon, pure embedding medium ( 2 changes) and polymerization at $70^{\circ} \mathrm{C}$ for approximately $15 \mathrm{~h}$.

Thin sections (in all cases) were made with a Sorvall Ultramicrotome. Uranyl acetate ( $2 \%$ for $15 \mathrm{~min}$ ), followed by leaf citrate $(5 \mathrm{~min})$, was used for staining. Dip preparations were also made. These were fixed in $1.5 \%$ 
glutaraldehyde in .1 M sodium cacodylate buffer $\mathrm{pH}$ 7.2. Fixed preparations were negatively stained with $2 \%$ phosphotungstic acid (PTA) pH 7.0. A Siemens Elmiskop 1A electron microscope at $80 \mathrm{kv}$ was used to study the specimens.

\section{RESULTS}

\section{TRANSMISSION STUDIES}

Symptoms of the disease could not be reproduced by inoculating healthy test plants in various stages of growth with extracts obtained from the foliage of affected pigeon pea plants. Plants such as Nicotiana tabacum, N. glutinosa, Cucumis sativus, Chenopodium amaranticolor, Capsicum annuum and Phaseolus vulgaris also failed to develop symptoms after inoculation via the same means.

The grafts of infected scions failed to grow or to incite disease symptoms. Some of the grafts on healthy plants using healthy scions were successful.

Transmission of the agent by means of the surgical cannula grafting method was not achieved. The diseased tissues inserted via the cannula failed to become established in the recipient plants.

\section{STUDIES ON REMISSION OF SYMPTOMS}

There was complete remission of symptoms of witches' broom on greenhouse and field plants where insects were destroyed with insecticides. About three and a half weeks after the insects were eliminated, supernumerary axillary shoots, shortened nodes, ear-shaped chlorotic leaves and other symptoms associated with witches' broom were not evident on the new shoots of these plants. However, the test plants which remained colonized continued developing the typical witches' broom symptoms as described above. There was a marked reduction in growth. Variety 02115 was seriously affected by insects, and developed more severe symptoms than the Kaki variety. This was also evident in later trials carried out in the field.

EFFECT OF THE NUMBER OF INSECTS ON INCIDENCE AND SEVERITY OF SYMPTOMS

Slight curling of the topmost leaves occurred when plants were colonized with single insects.

One week after colonization, plants with five insects were somewhat shocked, but no burning nor necrosis was evident on their leaves. Slight twisting and tip burn of the younger leaves were evident in some cases. Growth was in no way affected.

In the specific case of the treatment with 10 insects per cage, visible damage was evident on each of the plants at the end of 3 weeks. The 
plants presented moderately severe leaf curl, chlorosis, tip and side burn of leaves and a moderate leaf loss. Such plants were about half the size of controls 1 month after the trial was initiated. Loss of apical dominance and emergence of multiple axillary shoots were evident at the end of 2 months.

When the number of insects per pot increased to 25, markedly severe symptoms were evident on each of the test plants. One month after initiation of the trial, witches' broom was severe in all cases and the leaves were extremely small. Severe chlorosis, leaf curl, stunting, defoliation and loss of apical dominance were evident on all plants of this

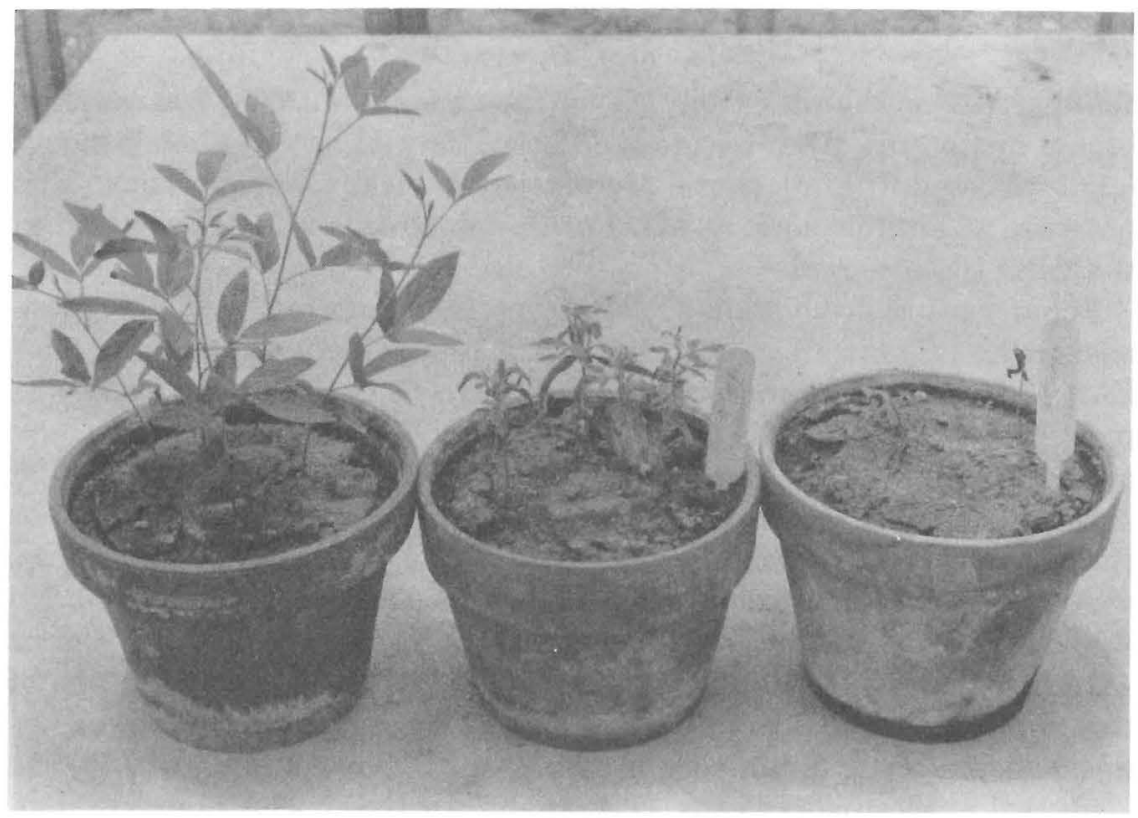

FiG. 3.-Effect of 10 and 25 insects per treatment on pigeon pea plants in the 3-leaf stage.

treatment. The appearance of these symptoms would certainly justify the name of the disease, that is, witches' broom. Clear-cut apical necrosis occurred in many cases. Stunting of the plants was typical (such plants were still smaller at the end of the trial than those of the previous treatment) (fig. 3).

The plants belonging to the last treatment (50 insects per pot) suffered apical necrosis and many emerging shoots also became necrotic. Such plants presented supernumerary axillary shoots and foliar chlorosis. All failed to recover. Many of the plants tested were on the verge of death after the third week. 
After 2 months all plants that did not succumb in the aforementioned trials recovered from symptoms some time after the insect colonies were destroyed by spraying, or when the plants were decolonized. This was true in the case of plants which at the beginning of the trial were in the six-leaf stage. However most of the smaller plants (3-leaf stage at initiation of trials) failed to recover.

Five different disease intensities, ranging from mild to severe, could be observed. Severity of the malady augmented with an increase in the number of leafhoppers employed.

Non-colonized control plants (also employed in a 1:1 ratio) in all cases remained healthy throughout the duration of the tests.

\section{ELECTRON MICROSCOPY}

Foliar tissue samples from pigeon pea plants with typical witches' broom symptoms, from naturally infected as well as greenhouse inoculated material (fig. 4), were processed for electron microscopy. The presence of entities such as MLO or rhabdoviruses was not revealed in the foliar tissue samples.

Foliar tissues from plants with symptoms (mosaic) not like those observed on plants affected with witches' broom were also processed for EM. The symptoms prompted the author to denominate the malady as pale mosaic of pigeon pea (fig. $5 \mathrm{a}, \mathrm{b}, \mathrm{c}, \mathrm{d}$ ). This disease is characterized by a mild mosaic of the leaves, mainly the younger ones, vein necrosis, and subsequent yellowing. Abscission of affected leaves was common but not the rule. Necrosis was more pronounced with age. Rhabdovirus particles were observed in the cytoplasm of cells of plants thus affected (fig. 6). No rhabdovirus was detected in ultrathin sections made from foliar tissues of healthy plants. Until this moment, no MLO have been found in any of the samples obtained from pale mosaic-affected plants. The writer has not detected the simultaneous presence of MLO and rhabdovirus in the same cell or in adjacent cells. Only rhabdovirus particles in great quantities have been found in phloem parenchyma tissue of plants with pale mosaic (figs. 7 and 8).

However, MLO were found in the foliage of plants which exhibited symptoms (fig. 9) distinct from those of witches' broom and pale mosaic. In this case the whole plant or just one of its branches presents a marked reduction in growth and a very distinct and characteristic pale green color (fig. 10). There is a reduction in the leaf size and the stalk and petioles are thin and weak in relation to those of healthy plants. The disease in this case was denominated bushy canopy by the author. No rhabdovirus were found in cells of plants with such symptoms.

\section{DISCUSSION}

Results of the different trials and studies carried out to determine the cause of witches' broom and associated diseases of pigeon pea in Puerto 


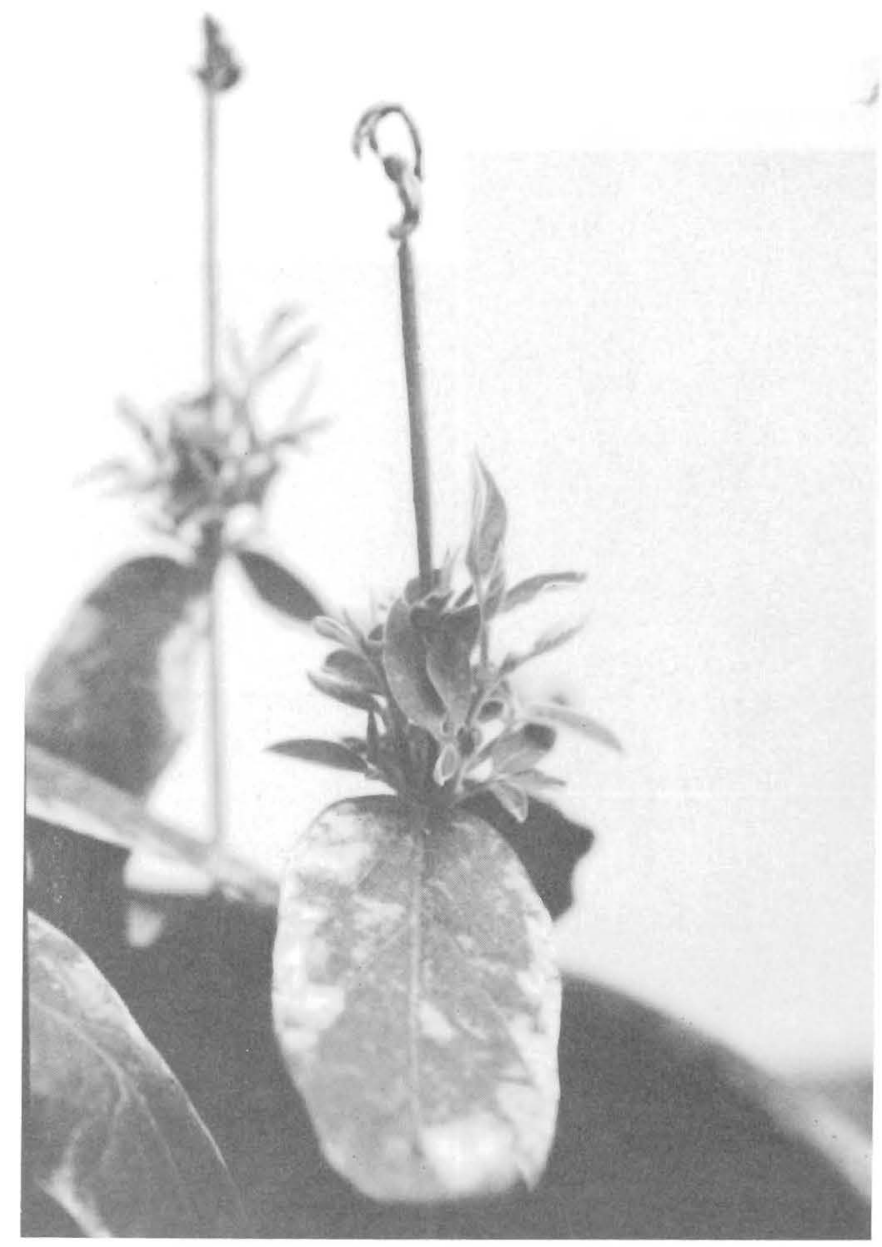

Fig. 4.-Pigeon pea plants (colonized in the greenhouse) exhibiting apical necrosis and witches' broom symptoms.

Rico show that the symptoms linked with witches' broom are caused by toxins injected by leafhoppers of the genus Empoasca. One, or perhaps two, species within the Empoasca fabae complex (E. kraemeri Ross \& Moore and E. millsi Ross) could be implicated in this specific disease. The fact that the typical disease was provoked by the continued presence of a colony of more than 10 insects and that symptoms in all cases gradually disappeared (towards complete and final recovery) on destruction of the insects is in itself fairly good evidence to substantiate this view. This view gains more strength when consideration is given to the fact that no virus-like particles or mycoplasma-like bodies were detected 


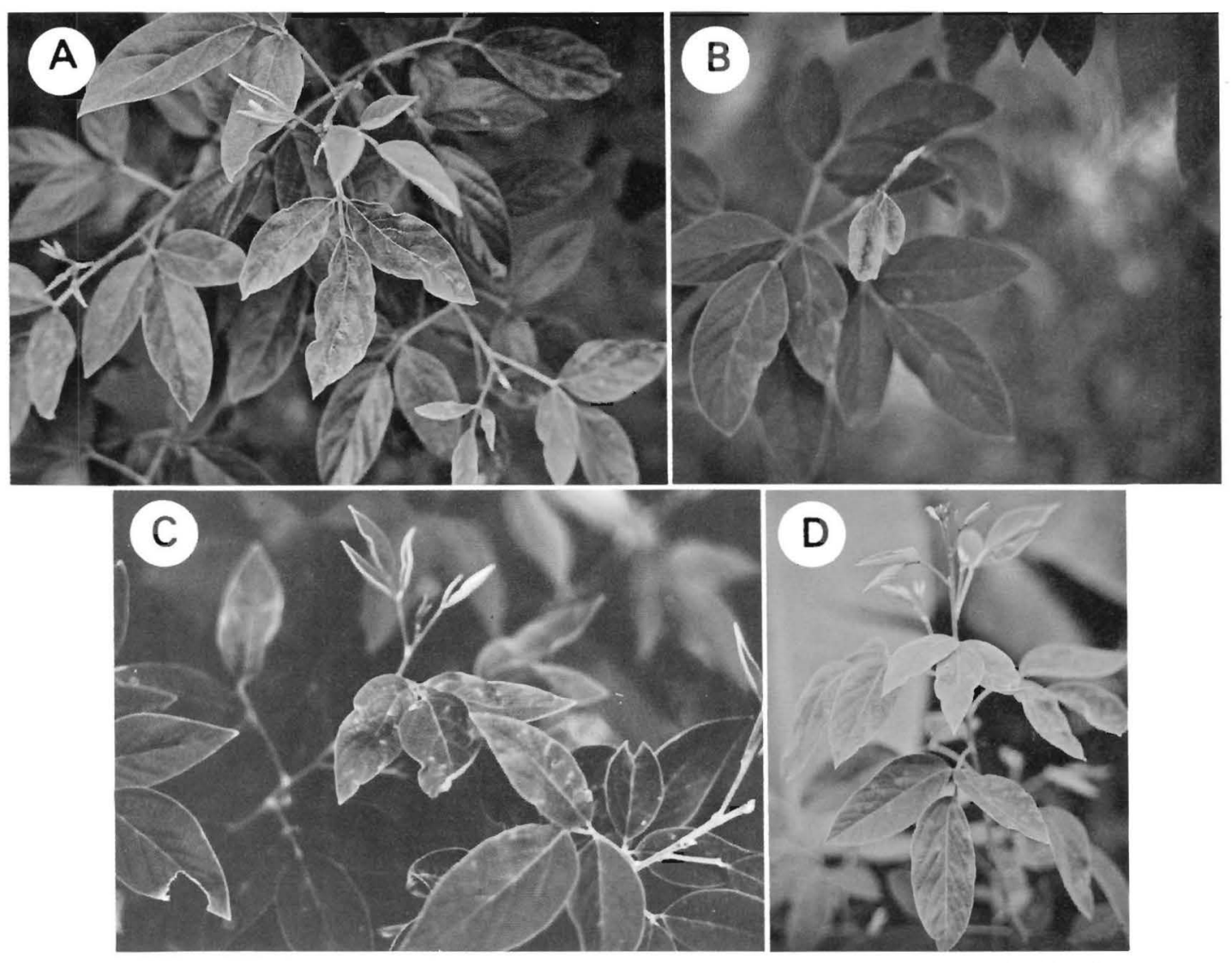

FIG. 5.-Pigeon pea plants exhibiting symptoms of pale mosaic. A, pale mosaic. B, pale mosaic affected leaflets showing yellowing and shrinking. C, pale mosaic. D, pale mosaic. 


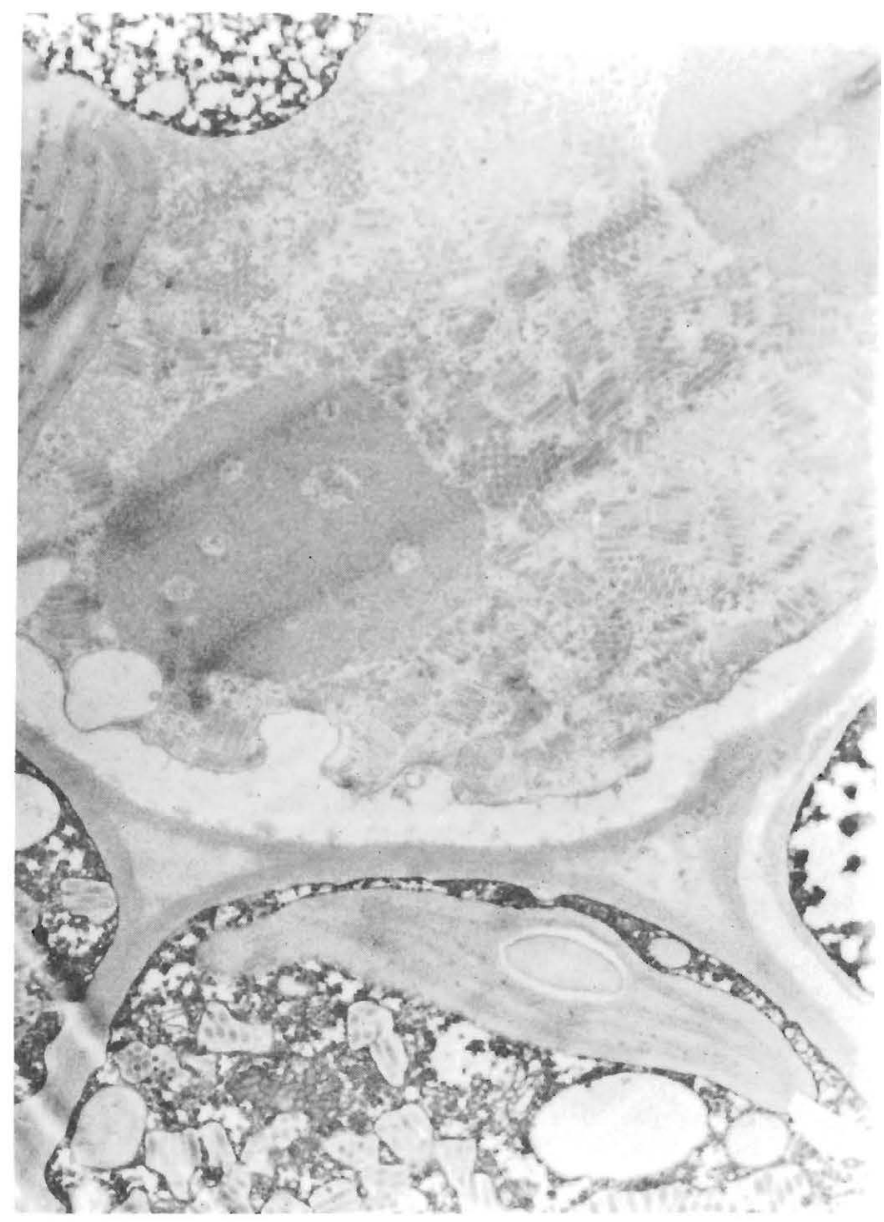

Fic. 6.-Rhabdovirus particles in the cytoplasm of a pigeon pea cell obtained from a pale mosaic-affected plant. $11,500 \times$.

in the foliar tissues of witches' broom-affected plants (from affected field or greenhouse specimens). As stated before, the witches' broom condition seems to be a direct consequence of the injection by leafhoppers of toxic substances into the tender top tissues of the pigeon pea plants. These tissues die back and are replaced by supernumerary axillary shoots which emerge soon after the loss of apical dominance. The fact that none of the indicator plants, including pigeon pea, developed disease symptoms after mechanical inoculation is also an indication that no virus is involved in the causation of pigeon pea witches' broom. 

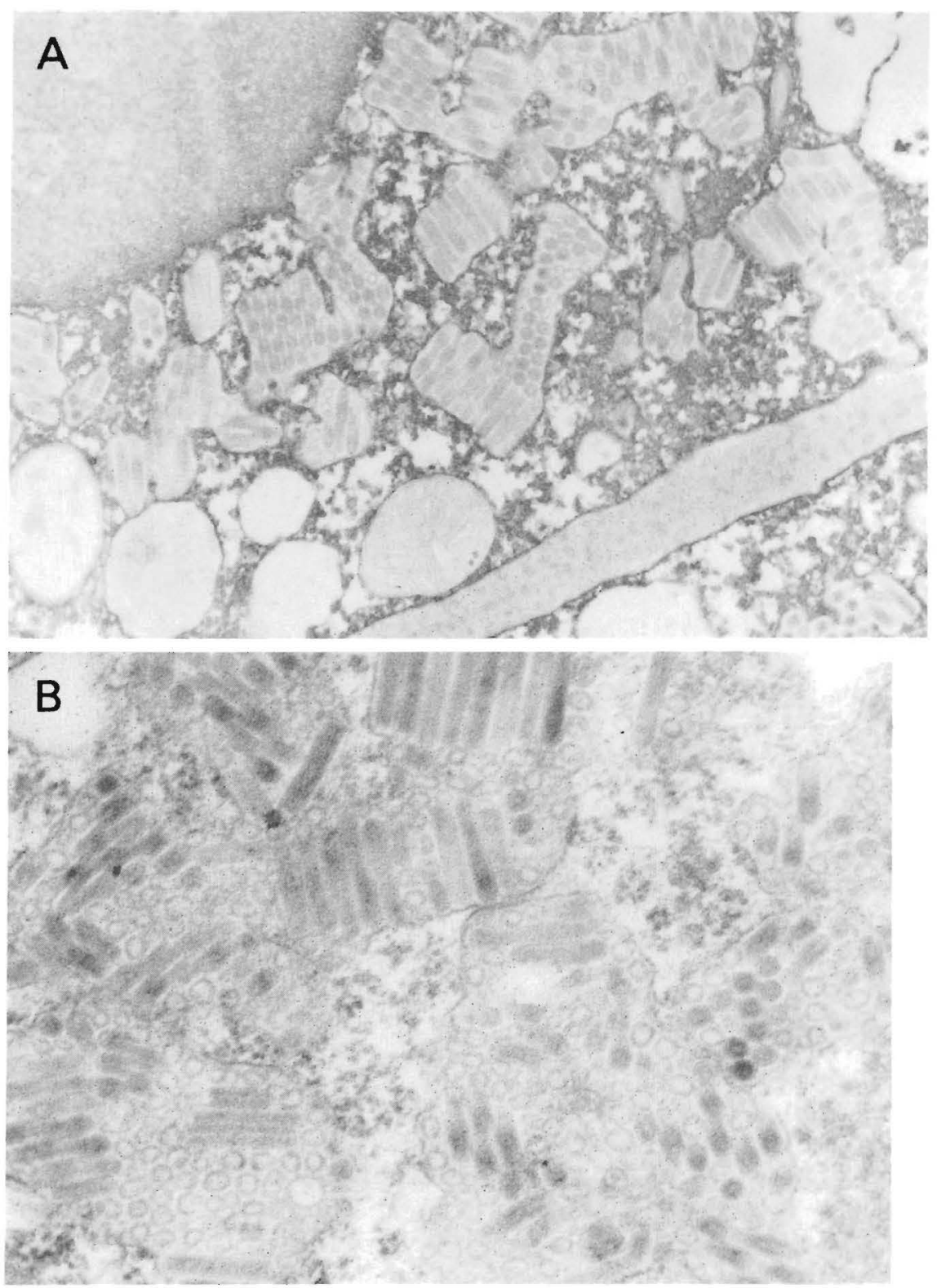

Frg. 7.-Rhabdovirus particles in plant tissues affected by pale mosaic. Note virus particles in transverse (t) and longitudinal section (1). A, 26,892 ×; B, 44,984 ×. 


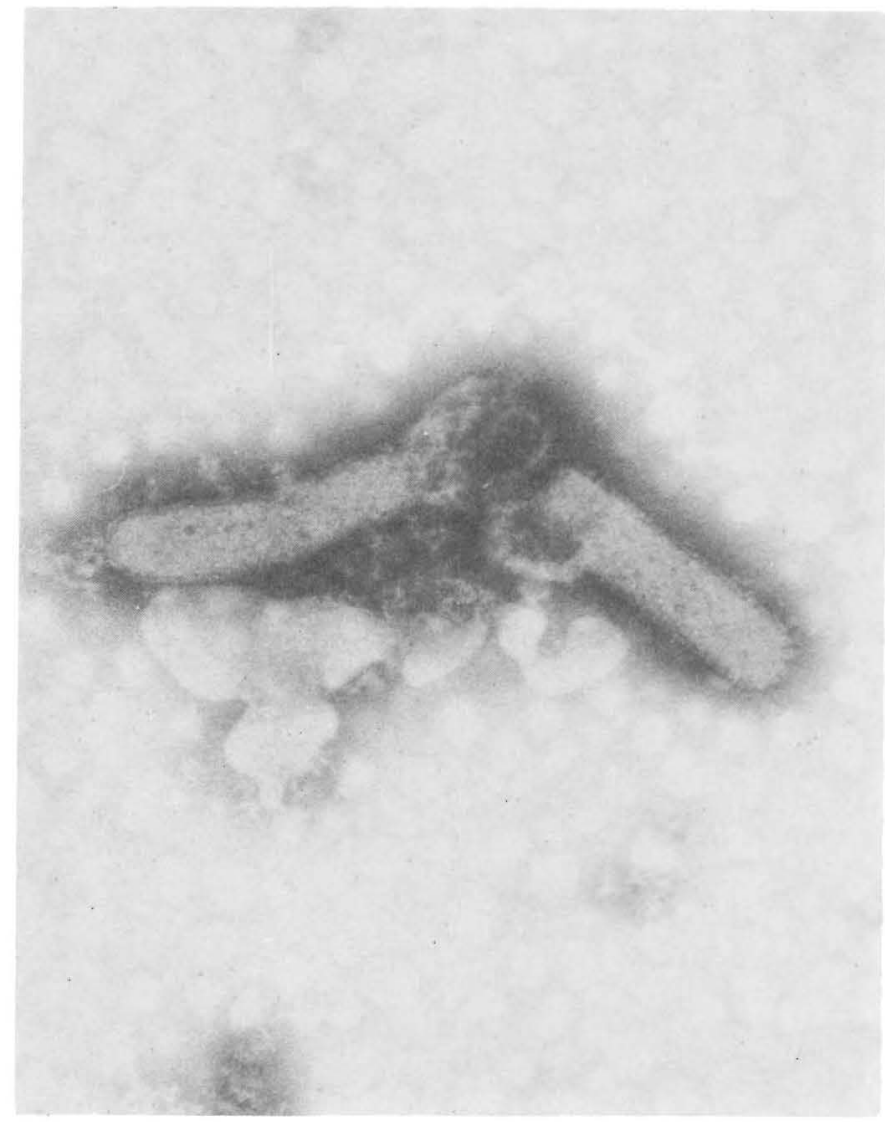

FiG. 8.-Rhabdovirus particles fixed in $1.5 \%$ glutaraldehyde in $1 \mathrm{M}$ sodium cacodylate buffer $\mathrm{pH} 7.2$ and negatively stained in $2 \%$ phosphotungstic acid $\mathrm{pH} 7.0 .106,894 \times$.

Failure to obtain transmission by grafting is of no consequence in this case. A good set is usually required for transmission of a nonmechanically transmitted virus by grafting. Therefore, the evidence obtained from the grafting studies is of no value whatsoever unless to indicate that tissues affected by witches' broom are deteriorated to the extent that they cannot withstand the adversity of grafting. Such was not the case with healthy pigeon pea tissue when grafted on healthy plants.

The witches' broom disease is believed by some to be caused by the combined action of mycoplasma and rhabdovirus (18). The writer has been able to reproduce the witches' broom disease by increased colonization of test plants with leafhoppers. Tissues of pale mosaic-affected 


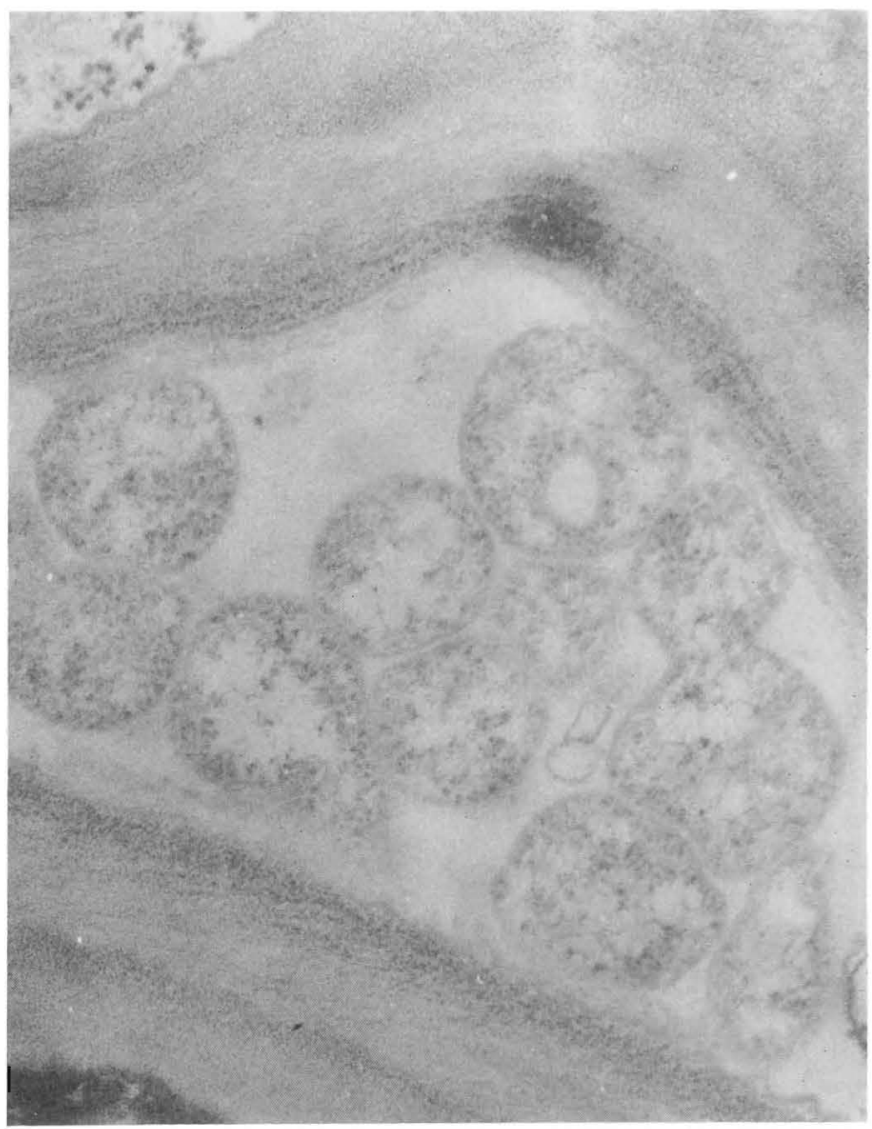

FIG. 9.-Typical mycoplasma-like organisms found in the foliage of plants affected by bushy canopy. $43,687 \times$.

plants (witches' broom-free, bushy canopy-free) consistently yielded rhabdovirus. Afterwards, MLO were found in fairly consistent association with the bushy canopy condition.

\section{RESUMEN}

Los resultados de diversas pruebas de inoculación, colonización progresiva con saltahojas así como la evidencia obtenida del estudio de secciones ultrafinas examinadas al microscopio electrónico indican que la escoba de bruja del gandul (Cajanus cajan) es provocada por toxinas inyectadas por saltahojas del complejo Empoasca fabae (Homoptera: Cicadellidae). Los síntomas del mal desaparecen si se retiran o reprimen los saltahojas. 


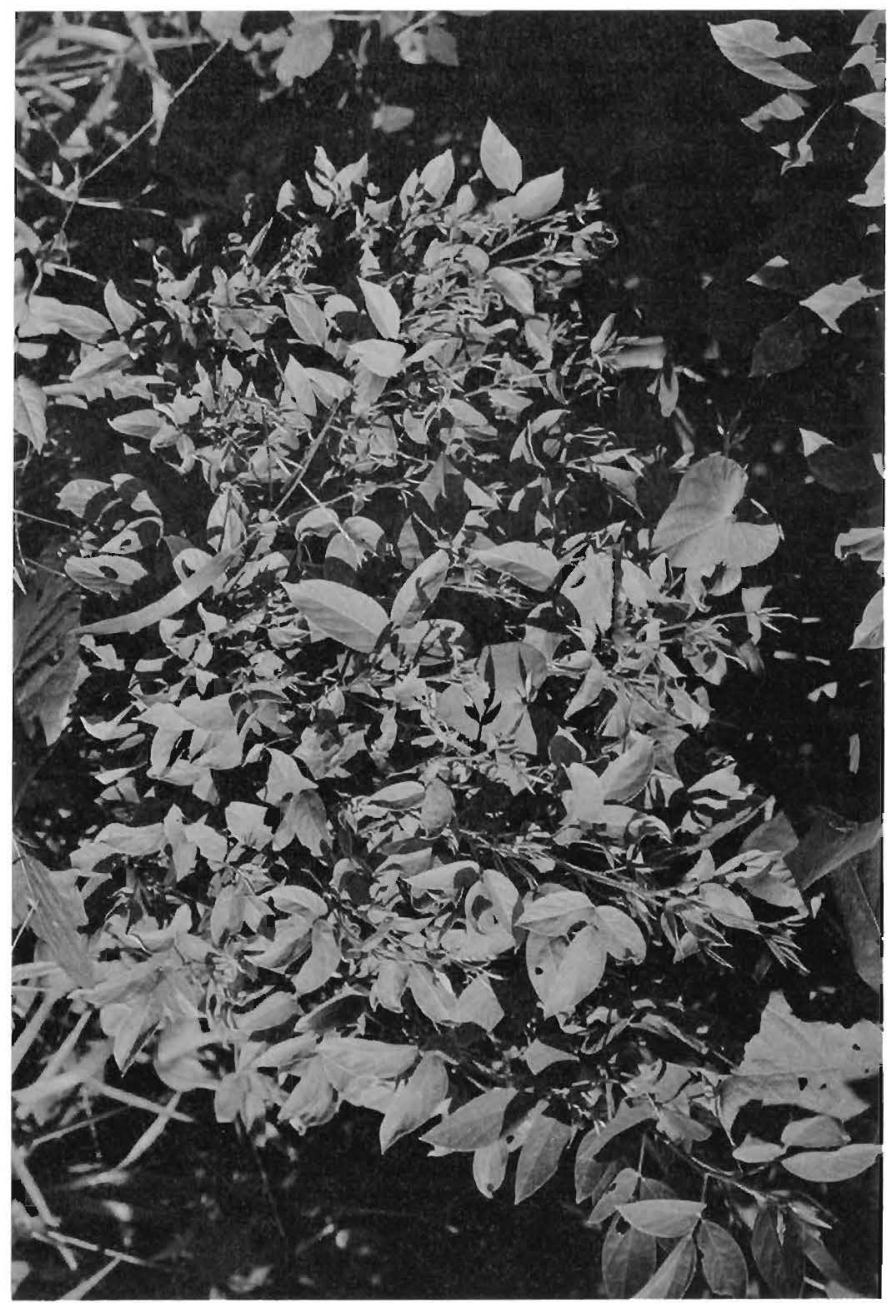

FIG. 10.-Bushy canopy condition exhibited by plants whose foliar tissues revealed mycoplasma-like organisms.

Se asoció por primera vez un rabdovirus con síntomas de mosaico en la planta de gandul. El virus no causa la enfermedad de escoba de brujas.

Se determinó que un organismo micoplasmoide está asociado con la enfermedad que la autora denominó "enanismo arbustivo" del gandul. Este mal prevalece en la región de Isabela y es distinto a los dos mencionados anteriormente. 


\section{LITERATURE CITED}

1. Abrams, R., 1975. Status of research on pigeonpeas in Puerto Rico. In International workshop on grain legumes, ICRISTAT: 141-147.

2. Barnes, R. R., 1973. A preliminary list of literature on pigeonpea (Cajanus cajan (L.) Mills.). Bull. 1, Dep. Biol. Sci., Univ. West Indies, St. Augustine, Trinidad.

3. Bird, J., Sánchez, J., Rodríguez, R. L., and Juliá, F. J., 1975. Rugaceous (whiteflytransmitted) viruses in Puerto Rico. Pages 3-25 In: J. Bird and K. Maramorosch (Ed) Diseases of Tropical Legumes, Academic Press, New York. $171 \mathrm{p}$

4. Caner, J., July, J. R., and Vicente, M., 1976. Characteristics of a rhabdovirus isolated from pea plants (Pisum sativum L.), Summa Phytopathologica 2: 264-269.

5. Davidson, R. H. and Peairs, L. M., 1966. Insect pests of farm garden and orchard, John Wiley \& Sons, New York. 675 p.

6. Davis, R. E. and Whitcomb, R. F., 1971. Mycoplasmas, rickettsiae and chlamydiae: 3525 possible relation to yellows diseases and other disorders of plants and insects, Ann. Rev. Phytopathol. 9: 119-54.

7. Fedotina, V. L., 1977. Virus particles and mycoplasma-like organisms in cell of oat with pseudo-rossette disease, Arch. Phytopathol. Pflanzenschutz 13: 177-191.

8. Francki, R. I. B., 1973. Plant Rhabdoviruses, Adv. Virus Res. 18: 257-345.

9. Giannotti, J., Vago, C., and Duthoit, J. L., 1968. Isolement et purification de microorganismes à structure de mycoplasmes à partir de cicadelles et de plantes infectées de jaunisses, Rev. Zool. Agr. Appl. 67: 69-72.

10. Granados, R. R., Gustin, R. O., Maramorosch, K., and Soner, N. W., 1968. Transmission of corn stunt virus by the leafhopper Deltocephalus sonorus Ball., Contrib. Boyce Thompson Inst. 24:57-60.

11. - Maramorosch, K., and Shikata, E., 1968. Mycoplasma: suspected etiologic agent of corn stunt, Proc. Nat. Acad. Sci. 60: 841-844.

12. Hayat, M. A., 1972. Basic Electron Microscopy Techniques, Van Nostrand Reinhold Company, New York, $119 \mathrm{p}$.

13. Hirumi, A and Maramorosch, K., 1969. Mycoplasma-like bodies in salivary glands of insect vectors carrying the aster yellows agent, J. Virol. 3: 82-4.

14. - Maramorosch, K., and Hichez, E., 1973. Rhabdovirus and mycoplasma-like organisms: natural dual infection of Cajanus cajan, Phytopathology 63: 202 (Abstr.).

15. Hull, R., 1971. Mycoplasma-like organisms in plants, Rev. Plant Pathol. 50: 121-30.

16. Lee, P. E., 1967. Morphology of wheat striate mosaic virus and its localization in infected cells, Virology 33: 44-94.

17. Maramorosch, K., Granados, R. R., and Hirumi, 1970. Mycoplasma diseases of plants and insects, Adv. Virus Res. 16: 136-87.

18. - Hirumi, H., Kimura, M., Bird, J., and Vakili, N., 1974. Diseases of pigeon pea in the Caribbean area: an electron microscopy study, FAO Plant Prot. Bull 22: 32-6.

19. - Kimura y, M., and Nene, Y. L., 1976. Organismos micoplasmoides asociados con la enfermedad de la roseta del gandul en la India, FAO Plant Prot. Bull. 24: 34-5.

20. - Shikata, E., and Granados, R. R., 1968. Structures resembling mycoplasma in diseased plants and in insect vectors, Trans. N.Y. Acad. Sci. 30: 841-55.

21. Matthews, R. E., 1970. Plant Virology, Academic Press, New York. 778 p.

22. Metcalf, C. L. and Flint, W. P., 1962. Destructive and useful insects, their habits and control, McGraw Hill Book Company Inc., New York. 1087 p.

23. Morton, J. F., 1976. The pigeonpea (Cajanus cajan Millsp.) A High Protein Tropical Legume, HortScience 11: 11-9.

24. Razin, S., 1969. Structure and function in mycoplasma; Ann Rev. Microbiol. 23: 317.

25. Saito, Y., Chaimongkol, V., Singh, K. G., and Hino, T., 1976. Mycoplasma-like bodies associated with rice orange leaf disease, Plant Dis. Rep. 60: 649-5I. 
26. Shikata, E., Maramorosch, K., and Ling, K. C., 1969. Presumptive mycoplasma etiology of yellows diseases, FAO Plant Prot. Bull. 17: 121-8.

27. Singh, R. and Mall, T. P., 1976. A new virus diseases of arhar Cajanus indicus (L.) Millsp. Current Sc. 45: 635-636.

28. Sinha, R. C., 1965. Recovery of potato yellow dwarf virus from hemolymph and internal organs of an insect vector, Virology 27: 118-9.

29. - 1968. Recent work on leafhopper-transmitted viruses, Adv. Virus Res. 13: 181220.

30. - 1973. Virus like particles in salivary glands of leafhoppers Endria inimica, Virology 51: 247-251.

31. - and Chiykowski, L. N., 1969. Synthesis, distribution and some multiplication sites of wheat striate mosaic virus in a leafhopper vector, Virology 38: 679-84.

32. Skerman, P. J., 1977. Tropical forage legumes, FAO, Rome.

33. Spence, J. A., 1975. The importance of diseases in relation to the grain legume research program in the eastern Caribbean, Pages 151-155 in J. Bird and K. Maramorosch, Ed Tropical Diseases of Legumes, Academic Press, New York. 171 p.

34. Vago, C. and Giannotti, J., 1977. Complex infection due to viruses, mycoplasmas and rickettsia-like organisms in the same cell in diseased plants. In Travaux dédiés à Georges Viennot-Bourgin. Paris, France. INRA Station de Recherches de Cytopathologie. Soc. Franc. Phytopathol. 393-403.

35. Vakili, N. G. and Maramorosch, K., 1973. Witches' broom disease caused by mycoplasmalike organisms on pigeonpeas (Cajanus cajan) in Puerto Rico, Plant Dis. Rep. 58: 96. 